\title{
CHANGE MANAGEMENT DECISIONS IN THE INFORMATION AGE
}

\author{
Vida Davidavičienè \\ Vilnius Gediminas Technical University, Saulettekio al. 11, Vilnius, Lithuania \\ e-mail:videl@vv.vgtu.lt \\ Received 13 June 2007; accepted 18 September 2008
}

\begin{abstract}
The work under new conditions of ICT development has not only advantages, but also causes certain challenges and new conflicts within an organization. There is a direct link between the development of ICT and business management theories. Inadequacy of models applied in change management and current market requirements can determine the decrease of competitive ability for the business organizations in the ICT caused business environment, what can cause loss of potential markets. The relations between ICT and business in the development processes and trends must be determined in order to avoid the gaps in business management methods in the future. While the schemes for evaluation and selection of alternative decisions are given much attention in the strategic management literature, the attention given to the specific implementation and the practical application of change management decisions methods is not sufficient. These circumstances frame the topicality of this subject.
\end{abstract}

Keywords: business change, management, information age, ICT, ICT development, good practice.

\section{Introduction}

Processes of information technologies and telecommunications (ICT) integration are becoming more powerful in the economic and political sectors. It creates conditions for a new cosmo politically global culture, which is free from any national restrictions. The work under new conditions of ICT development has not only advantages, but also causes certain problems as well as new conflicts within an organization. There is a direct link between the development of ICT, globalization processes, business management and management theories. Inadequacy of models applied in change management and current market requirements can determine the decrease of competitive ability for the business organizations in the ICT caused business environment, what can cause loss of potential markets. The relations between ICT and business in the development processes and trends must be determined in order to avoid the gaps in business management methods in the future. The perception of ICT caused business environment change management improve- ment problems and their solutions frame the topicality of this subject.

Theoretical models and their application practice do not consider change management caused by ICT development requirements. They are determined by pervasion of information technologies, development of virtual organizations as well as business under conditions of ICT evolution. Due to particularity of information technologies, new business change management problems are faced. Aim of the topic is to investigate specifics of the change management in ICT development conditions and present a model of decision search.

In the article systematic analysis was applied that allowed disclosing business change management specifics under the conditions of ICT development. In performing the research methods of comparison were used and special technique, fit to classify the various ICT projects, considering their goals, markets, users and lessons learned was employed, for evaluation of the ICT projects the expert analysis method was selected. 


\section{Challenges for business management caused by development of ICT}

Huge human potential to investigate and explore can be observed since the earliest ages. Scientists agree that relation between all kinds of human activities exists. But questions concerning the development and relations of different activities become important:

- Is this relation strong enough for influence on further development and human decision in social and business sectors?

- How strong is this influence in concrete situations?

- Are there any trends of this relation and development process?

- Are there possibilities for prognoses of the development and changes of separate business branches?

The research on the ICT and business development was made in order to evaluate the relation between them and possibilities to forecast further steps of changes. Due to ICT and business management development research the relations between the business, communications and computer technologies were identified (Elskytè 2006; Encyclopedia 2002; Ginevičius 2006; Kanter 1984).

A parallel between ICT and business identifies relation and it is tight since the earliest ages. Time periods between inventions of ICT or business management theories (or significant event) differ. The business management and technologies development timeline presents the main findings (Elskyte 2006 ):

- First management signs are found in ancient Egypt, Greece, and Babylon. At that time the changes in the business or technologies areas were very slow - over 500 years. The ABACUS machine, hieroglyphs, alphabet, paper and first marketing tricks and advertising on the walls go near.

- Second step, when Gutenberg's printing machine in 1454 was invented - the more educated society started various tricks in business (terms "advertising", "management" appear, advertisements in the newspapers becoming popular, etc.). At that time the changes were noticed each 100 years.

- Third step was in the $19^{\text {th }}$ century when technological inventions boost came: telegraph line of Chaper in 1793, electric telegraph of Henris in 1831, Morse's alphabet in 1835, telephone of Bell\&Watson in 1876 and parallel - earliest business management schools.

- The last cycle of changes started in the $20^{\text {th }}$ century when business management became a catalyst of ICT development and vice versa.
Main tendencies, which were detected during this research, were:

- time intervals between new discoveries decrease in timeline starting from the $20^{\text {th }}$ century: 20 years at the beginning, 10 years in the middle, 5 years at the end.

- the processes of business environment changes becoming faster and that is a challenge to management science.

The results stated that the underlying attention should be paid to:

1) Identification of management problems in the business environment affected by changes of information technologies;

2) Essential business management methods should be identified.

\section{Change management models in the context of ICT development}

In order to solve change management tasks in the dynamic business environment first of all the existing methods and models should be investigated and evaluated. Innovations, business changes, knowledge society and use of ICT in business problems are topics of many Lithuanian and foreign authors, but proposed attributes (methods and models) do not gather the change management and ICT practice, what enables to solve change management problems in organization in ICT development conditions. The innovations and change management are analysed by such authors as Castagnos, Castells, Champy, Davenport, Drucker, Guptara, Hamer, Henry, Kanter, Kleinknecht, Lewin, Minzberg, Strebel, West, Westley, etc. ICT integration questions are analysed by Alter, Azariadis, Edwards, Kroenke, O`Leary, Rashid, Ward, Webster, etc. (Casson 1998; Castells 2003; Champy 1995; Elskyte 2006; Encyclopedia 2002; Ginevičius 2006; Kanter 1984). Scientists analyze various models, management theories as separate systems. That is why the adopted for nowadays demands and challenges solutions are not clear enough. Analysis also leads to the conclusion, that in ICT development conditions the traditional 'step by step' methods of business management are not efficient, so more drastic ICT caused business change management methodology is needed.

Gaps in change management theories were detected considering rapid changes caused by ICT. In the approach methodology accent is on consequent change implementation (for example, Kanters' model; Lewins' model), which is quite complicated in information age conditions, when markets are so dynamic. In the emer- 
gent methodology changes are related to strategy planning and to actions after that, but most of the models are not oriented to rapid changes (for example, five forces model). As one of most relevant models P. Strebel's (Strebel 1996) matrix was detected.

During the planning of changes within organization the prognosis of market changes is necessary (breakpoint prognosis, the cause of them can be, for example, new ICT product which creates new value for users). Very important point in the change management becomes integration of the organizational changes related to ICT into business process. There can be defined many different situations and organization positions in changing environment. Change management solutions should be classified by level of resistance:

- Discontinuous paths - recommended for organizations where the resistance to changes is strong. The dominating culture of resistance should be determined in order to create the convenient environment to those who will implement changes.

- Mixed paths - recommended for organizations where the resistance to changes is medium. The top managers should support those who are the initiators of changes.

- Continuous paths - recommended for organizations where the resistance to changes is weak. The experiments should be stimulated by top management in order to induce incoming changes.

The ways of change implementation, which are relevant to the conditions of information age, were taken from P. Strebel matrix (see Fig. 1) (Elskyte 2006). When the strength of force of changes is medium the recommended solutions are the following: (1) raising tasks, (2) business process reengineering, (3) regrouping organization. When the strength of force of changes is strong (4) rapid adaptation, (5) individual restructuring and (6) radical restructuring are recommended.

In order to use these methods and choose the most appropriate solution how to implement an innovative idea, which has to be new in a specific situation, good practice examples are needed. If an organization has no idea how to act, although changes are necessary, a good practice database is one of the most appropriate tools for solution search. The use of knowledge base makes it possible to shorten a life cycle of various projects when the analysis, planning and implementation processes can be shortened by acting according to the practice of another organization. Reengineering is one of the most relevant solutions in our changing environment, but it is quite risky and very drastic. For ensuring minimal risk of implementation of innovations (ICT changes) the project management methods are recommended.

The need for two trends of decision making process and ICT solution search were differentiated during the research:

1) when an organization has to respond to the changes which arise in the market, it needs an idea how to react; when the idea is generated the best way of its implementation should be identified,

2) when an organization wants to take competitive advantage via creating break-even in the market by implementing ICT innovations and has a specific idea how to achieve that. Then the question arises: what way of implementation should be chosen to apply that idea.

Therefore the following conclusion can be made: in dynamic business environment the use of knowledge base is necessary.

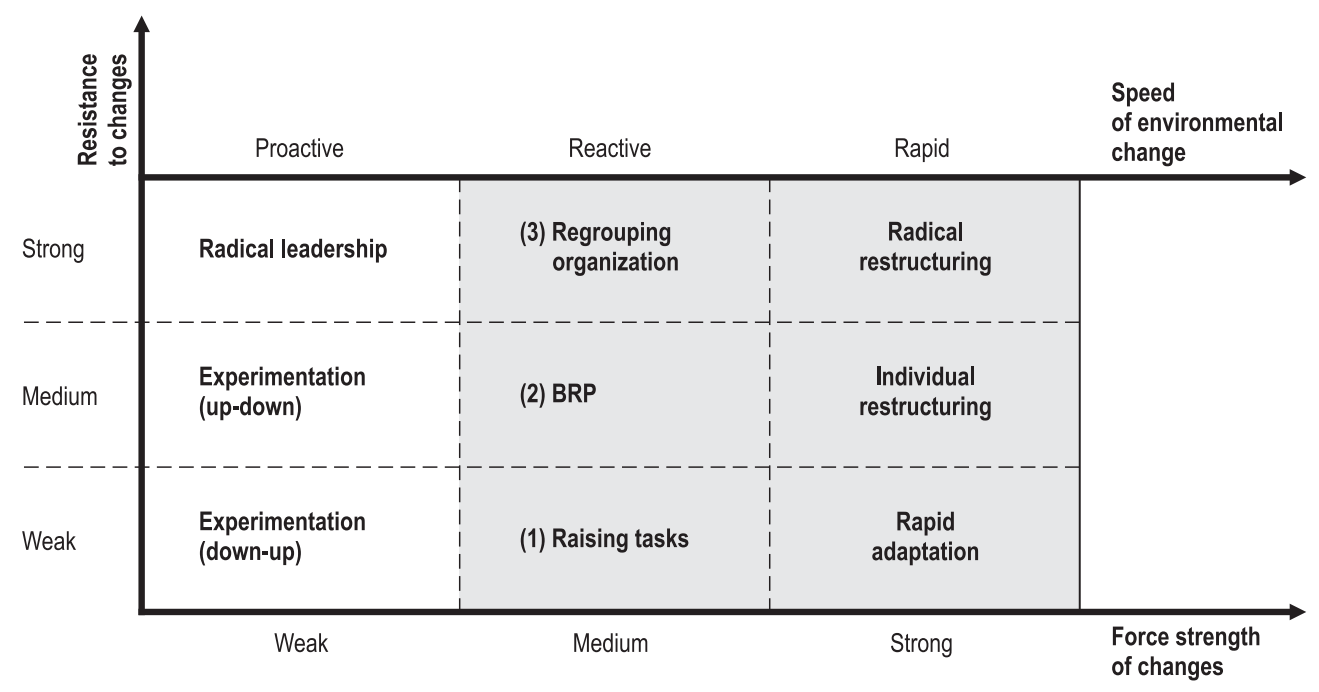

Fig. 1. Model of change management solutions 


\section{Good ICT practice - the source of change management}

Good ICT practice will not only enable a company to search for relevant cases, but it will also make useful comparisons among companies, industries and countries possible.

In spite of increasing ICT activity, relatively few proper databases containing examples and cases of companies exist. For that reason a more detailed analysis of only three sources was made: "Beep Knowledge System" (BEEP... 2006), "E-Market Services" (E-Market services...2005),"National best practices" (National best practices...2005). Putting focus on the existing resources, Beep proved to be the most helpful for any company with ICT implementation intentions. BEEP cases and supporting services are simple to use, moreover, the knowledge base, built upon knowledge management principles, covers five "domains": work and skills, the digital SME, social inclusion, regional development and e-government.

The four levels of hierarchy in BEEP include:

1) domains (domain is an area of knowledge or interest, and is subdivided in itself);

2) objectives (each domain is divided into a number of objectives, defined as "what you want to achieve");

3) key factors (each objective is divided into a number of key factors, defined as "how to achieve it");

4) indicators (usage of one or more indicators allows to measure (benchmark) key factors. Indicators are either quantitative or qualitative).

This knowledge base is suitable for easy data management but is not targeted for decision makers. The BEEP can become a prototype or the main tool for a change management model in the information age. However, its knowledge base should be made user- friendly by changing its dimensions to make it easier to study a case under specific business conditions. The result of the study of BEEP and main user needs enables us to prepare a change management model in ICT development environment.

The following dimensions describing the ICT projects and allowing to classify them were extracted during the analysis:

1) aim of the project (for example, improving communications);

2) market coverage (the rate of the usage of an ICT solution);

3) ICT user (who is the main user which takes advantage of new possibilities provided by ICT);
4) ICT means (theoretical models and rules for practical usage);

5) ICT purpose (knowledge on practical ICT usage);

6) business field (what kind of activities an organization proceeds via ICT);

7) country (where the ICT project was initiated);

8) investments (costs of implementation and exploitation);

9) results (lessons and project success story).

After the evaluation of BEEP dimensions three of them were identified to be most appropriate. The scale of these dimensions is described by the following key characteristics:

Dimension 1 - market coverage: global (the activities of an organization target the markets of different countries), intraglobal (departments of an organization are in different countries), local (an organization operates in one country), intralocal (departments of an organization are in different cities of a country);

Dimension 2 - ICT users: employees, business units, end user, special group of end users;

Dimension 3 - objectives of the ICT project: new business, knowledge management, communication improvement, additional business trend, sales improvement, etc.

These findings lead to deeper research on knowledge base and good ICT practice cases for the reason that the necessity of the classification of ICT cases is one of the main issues in change management.

The results of the research on good practice database are the following: typical criteria and indicators were identified as well as dynamics, trends and tendencies were uncovered (Elskytė 2006). Six main paradigms (paradigm - is a knowledge basket of similar ICT projects) of ICT usage, which are described by key dimensions are presented below:

- $\mathbf{P}_{\mathbf{1}}$ is recommended for organizations which act in global markets or have distant departments. The paradigm joins all cases of ICT usage in an organization when ICT users are employees of the organization. The aim of an ICT usage in most cases is to improve communications, to manage knowledge, and to improve information storage, etc.

- $\mathbf{P}_{2}$ is recommended for organizations which act or plan to act in global markets and do not have distant departments. The paradigm joins all cases of ICT usage in an organization when ICT users are business units who use virtual environment for information spread, contracting or offering rent of virtual environment for other business units. The aim of ICT 
usage in such cases is to run new business or service besides the main activities of a company,etc.

- $\mathbf{P}_{3}$ is recommended for organizations which act or plan to act in the local market. The paradigm joins all cases of ICT usage in an organization when ICT users are employees (as administrators and as customers). The aim of the ICT usage in such cases is to increase sales, to conquer new markets, etc.

- $\mathbf{P}_{4}$ is recommended for organizations which act or plan to act in the local market and are oriented towards EU funding. The paradigm joins all cases of ICT usage in an organization when ICT users are specific social groups. The aim of the ICT projects in such cases is to increase sales by means of collaborating with non-profit organizations, to assist in preparation of ICT projects, to implement them, etc.

- $\mathbf{P}_{5}$ is recommended for organizations which act or plan to act in the intraglobal market (employees are spread widely from the geographical point of view). The principles of business processes can change drastically. The paradigm joins the overall ICT usage in the cases of an organization when ICT users are employees, whereas, customers feel minimal changes after the implementation of new ICT. The aim of ICT usage in such cases is to lower administration and exploitation costs, to organise work processes by ICT means.

- $\mathbf{P}_{\mathbf{6}}$ is recommended for organizations which act or want to act more efficiently in the intralocal market. The principles of business processes can change drastically. The paradigm joins all cases of ICT usage in an organization when ICT users are employees. The aim of ICT usage in such cases is to increase efficiency of services, to decrease administration costs, etc.

Similar ICT projects must be evaluated in the search process of the solutions for change management and only one should remain after the evaluation.

\section{Change management model application}

The results of the research allow to identify two different situations, when a solution and the examples of good practice cases are required. The need for solutions of change management under ICT development conditions can arise in the following circumstances: when an organization seeks for an idea of an ICT project and when an organization seeks for a better way of implementation of ICT (see Fig. 2).

Three dimensions to identify an ICT project idea and know-how are foreseen and another three-dimensional spaces to find the method of implementation are proposed. Consequently, the space of six dimensions is recommended to be used in the change management model. The user who seeks for ideas or wants to compare their own ideas with the real ICT practice can act upon the first (three dimensions) way and afterwards proceed to the second one - the way of implementation search.

The principles of the ICT caused change management solution by the use of ICT good practice case search and evaluation are presented in the form of an algorithm (see Fig. 3).

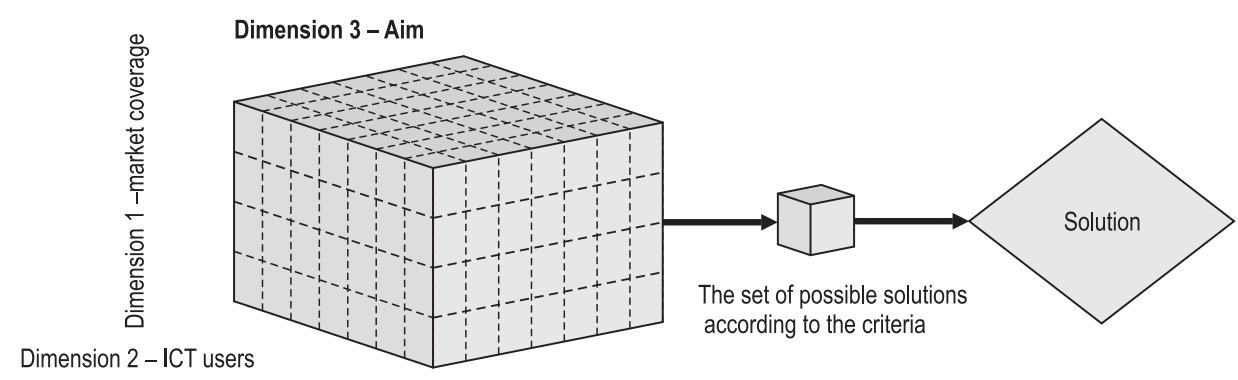

(1) ICT project idea search

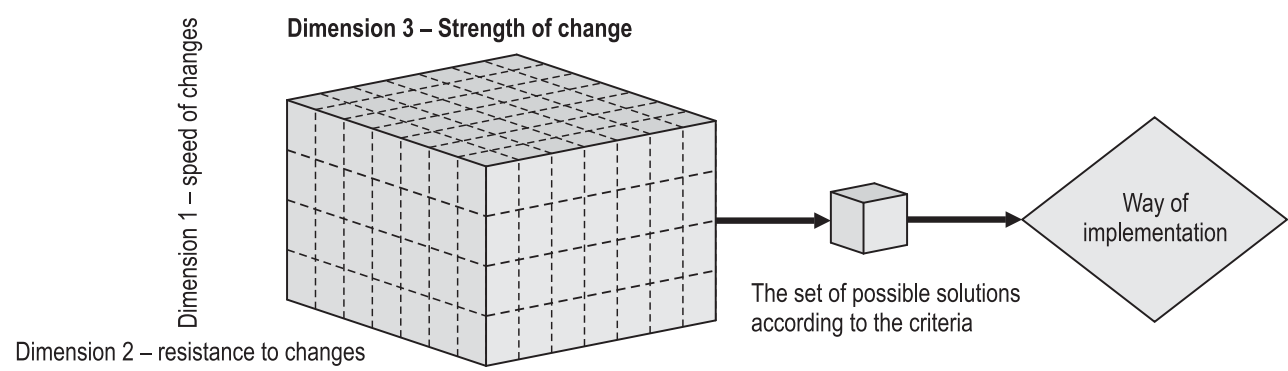

(2) Way of change implementation

Fig. 2. Ways of ICT solution search (Elskytè 2006) 


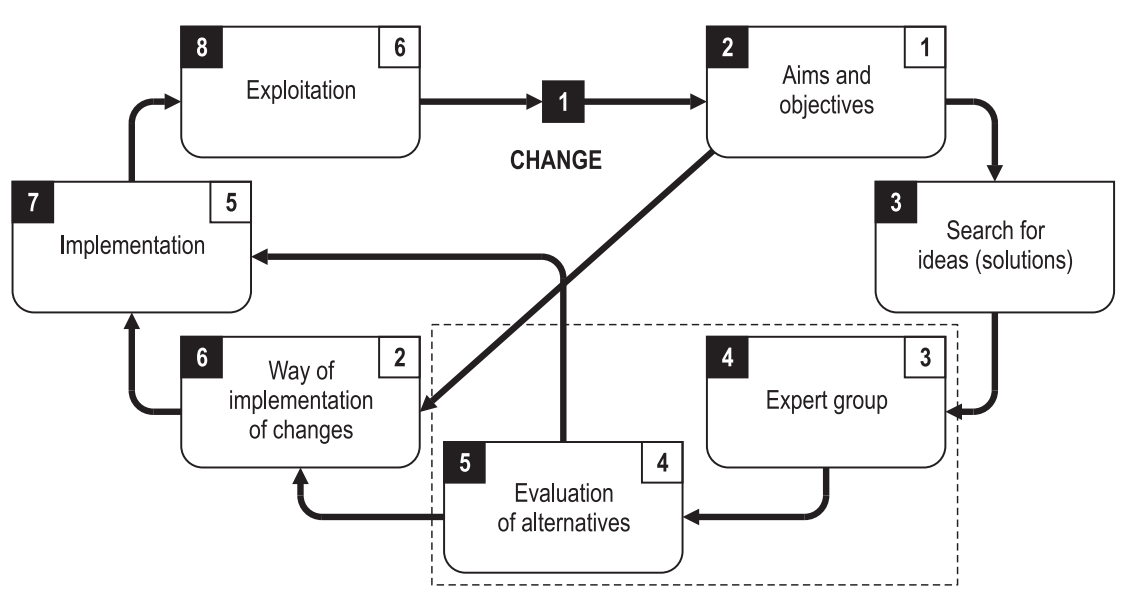

Fig. 3. Change management solution search algorithm (Elskytė 2006)

I. The first way (marked in blue boxes) is when the change in the market appears and the reaction (solution) to these changes is needed, will be presented by solving an experimental task (search for an ICT good practice case). To do this such steps should be followed:

1. Change. The evaluation of the business environment and the situation of an organization.

Example situation. An industrial company is seeking for a solution in change management by implementing a new ICT. This company operates and sells its products in the local market; sales department is responsible for the sales of the fodder. Their product is specific and that is the competitive advantage by which they expect to conquer new markets. Nevertheless, this company has no opportunities to start the trade in other countries because of expenses, but they have an idea to solve some trade challenges by implementing ICT in their business process and to conquer new markets by using some technological means. The potential users of ICT are customers of the new markets and the existing customers who are open-minded, ready and want to make use of ICT advantages.

2. Aims and objectives. Current and targeted market coverage should be defined, the aims and objectives of an organization in ICT change environment have to be made clear and potential ICT users should be described.

Example situation. After the evaluation of situation the following main search criteria can be determined: market coverage - local or global markets; ICT users - potential customers of a company (are open for technologies and new ways of communication); aim entering and conquering new markets by ICT means.

3. Search for ideas (solutions). When these three main criteria are defined, the next step is to identify the most relevant paradigm from the whole list of cases (knowledge base).
Example situation. According to the query two paradigms are detected in the database $\mathrm{P}_{2}$ and $\mathrm{P}_{3}$. During the experimental task an assumption was made that each paradigm gathers three ICT practice cases. $\mathrm{P}_{2}-$ Global Recycle, Mondus, Bobex (cases are related to service sector, so if this paradigm is decided to be chosen, radical changes emerge) and $\mathrm{P}_{3}-$ Manitoulin, Gifts of Course, Roundstone musical instruments (cases analyse communication, the quality of service provided for customers via ICT means, conquering new markets, etc.). For further evaluation the $\mathrm{P}_{3}$ paradigm is chosen. Short descriptions of each case are presented in Table 1. More detailed descriptions can be found in the databases such as BEEP.

4. Expert group. The next step is to evaluate the cases of the chosen paradigm and to detect the most relevant ICT project ideas. For the reason that evaluation of alternative ICT solutions is quite difficult and because they differ from each other in descriptions, lessons learned and indicators, the expert method as the most relevant one is suggested. Thus, an expert group should be gathered to evaluate alternative projects.

5. Evaluation of alternatives. Evaluation should proceed in such a way:

- First of all, the expert group determines the list of criteria. Experts can prepare the list or adopt the suggested one.

Example situation. Project life cycle $\left(\boldsymbol{K}_{\mathbf{1}}\right)$, project implementation time $\left(\boldsymbol{K}_{\mathbf{2}}\right)$, and communication with customer time interval possibilities $\left(\boldsymbol{K}_{\mathbf{3}}\right)$, the quality of project's administration and exploitation $\left(\boldsymbol{K}_{\mathbf{4}}\right)$, changes of market size $\left(\boldsymbol{K}_{\mathbf{5}}\right)$, customer service time changes $\left(\boldsymbol{K}_{\mathbf{6}}\right)$, and costs $\left(\boldsymbol{K}_{7}\right)$. The criteria can be qualitative and quantitative.

- Weights and scores can be largely subjective, so each expert according to the objectives indicates weight of each criterion in each project by filling in the matrix (see Table 2). 
Table 1. Description of cases of $\mathrm{P}_{3}$ paradigm

\begin{tabular}{|c|c|c|}
\hline Roundstone Musical Instruments & Manitoulin & Gift of Course \\
\hline $\begin{array}{l}\text { Roundstone decided to set up a website } \\
\text { in } 1995 \text {. Its website was placed online } \\
\text { in } 1996 \text { and further developed in } 1997 .\end{array}$ & $\begin{array}{l}\text { A remote transport company offers cus- } \\
\text { tomers the same high quality service as } \\
\text { national carriers by using ICT. }\end{array}$ & $\begin{array}{l}\text { Belgian SME deployed an e-commerce } \\
\text { solution (website) to dramatically in- } \\
\text { crease sales. }\end{array}$ \\
\hline $\begin{array}{l}\text { Most features, including e-commerce, } \\
\text { were already in place in the initial }\end{array}$ & $\begin{array}{l}\text { Geographic setting: Manitoulin Island, } \\
\text { Ontario, Canada. }\end{array}$ & \\
\hline $\begin{array}{l}\text { website. } \\
\text { Geographic setting. Roundstone is a } \\
\text { small fishing village in the Connemara } \\
\text { area of County Galway, western Ire- } \\
\text { land. }\end{array}$ & $\begin{array}{l}\text { Type and use of ICT: } \\
\text { Website offers customised } \mathrm{B} \\
\text { commerce solutions. } \\
\text { Main contributors: Compan } \\
\text { ment, sales and sales suppo }\end{array}$ & \multirow{5}{*}{$\begin{array}{l}\text { Type and use of ICT: servers and ter- } \\
\text { minals, portable PCs, LAN, Internet, } \\
\text { intranet, extranet, VPN, Broadband } \\
\text { communications: ISDN and TV cable, } \\
\text { Office automation, databases, Email } \\
\text { and voice mail. } \\
\text { Background: Gifts of Course began in } \\
1994 \text { as a giftstore with theFlemishname } \\
\text { Mandjevol. The store, which sold fresh } \\
\text { fruit baskets, was recognised by local } \\
\text { entrepreneurs as the most creative start- } \\
\text { up in the Flemish region of Belgium. } \\
\text { FruitOfCourse.com was launched } \\
\text { in } 1998 \text { to provide an answer to } \\
\text { serve customers who cannot physi- } \\
\text { cally visit the store. FruitOfCourse } \\
\text { was selected as one of the top } 5 \\
\text { Belgian e-commerce sites only } 10 \\
\text { months after it had been launched. } \\
\text { Now renamed GiftsOfCourse.com, the } \\
\text { collection of products and services of- } \\
\text { fered meets the needs of companies and } \\
\text { consumers who would like to deliver } \\
\text { high quality and original gifts around } \\
\text { the world, and Europe in particular. }\end{array}$} \\
\hline $\begin{array}{l}\text { Type and use of ICT: } \\
2 \mathrm{PCs} \text { operating on Windows, } \\
2 \text { Printers, } 1 \text { ISDN line, Internet, Data- } \\
\text { bases, Word processing, Graphic work. } \\
\text { The site was hosted with an external } \\
\text { provider. }\end{array}$ & $\begin{array}{l}\text { Main beneficiaries: Any size business } \\
\text { in logistics or similar market, particu- } \\
\text { larly those with remotely located of- } \\
\text { fices and dispersed sales force. }\end{array}$ & \\
\hline $\begin{array}{l}\text { Background: Roundstone Musical In- } \\
\text { struments, a manufacturer of the tra- } \\
\text { ditional Irish instrument known as the } \\
\text { bodhrán, is located in Roundstone, Ire- } \\
\text { land. Established in } 1978 \text { by Malachy } \\
\text { and Anne Kearns, the firm operates in } \\
\text { a very small but growing niche. }\end{array}$ & $\begin{array}{l}\text { Background: Manitoulin Transport } \\
\text { was originally incorporated as Smith's } \\
\text { Wholesale (Manitoulin) Limited in } \\
\text { 1953. Through the years, Manitoulin } \\
\text { Transport has slowly grown to be one } \\
\text { of Canada's largest freight manage- } \\
\text { ment providers. Manitoulin Transport }\end{array}$ & \\
\hline \multirow{2}{*}{$\begin{array}{l}\text { The Internet has also played an impor- } \\
\text { tant part in this development, especially } \\
\text { in foreign markets. About } 20 \% \text { of busi- } \\
\text { ness is now conducted online and the } \\
\text { company received numerous awards in } \\
\text { recognition of its success on the web. } \\
\text { Roundstone did not have much money } \\
\text { to spend on marketing. Export markets } \\
\text { make up } 73 \% \text { of the total sales. }\end{array}$} & $\begin{array}{l}\text { providing service to anyone who wants } \\
\text { to ship freight virtually anywhere in } \\
\text { North America. }\end{array}$ & \\
\hline & $\begin{array}{l}\text { Objectives: Improve customer service } \\
\text { by providing an on-line tracking func- } \\
\text { tion for shippers. }\end{array}$ & \\
\hline
\end{tabular}

Table 2. Comparison of criteria matrix

\begin{tabular}{ccccccc}
\hline Criterion & $\boldsymbol{K}_{\mathbf{1}}$ & $\boldsymbol{K}_{\mathbf{2}}$ & $\ldots$ & $\boldsymbol{K}_{\boldsymbol{c}}$ & Weight $(\mathbf{2}+\mathbf{3}+\ldots+\mathbf{5})$ & Weight coefficient \\
\hline $\boldsymbol{K}_{\mathbf{1}}$ & 0 & & & & $S_{1}$ & $X_{1}=S_{1} /(n \times c)$ \\
\hline $\boldsymbol{K}_{\mathbf{2}}$ & & 0 & & & $S_{2}$ & $X_{2}=S_{2} /(n \times c)$ \\
\hline$\ldots$ & & 0 & & $\ldots$ & $\ldots$ \\
\hline$K_{\boldsymbol{c}}$ & & & 0 & $S_{c}$ & $X_{n}=S_{n} /(n \times c)$ \\
\hline
\end{tabular}

Where: $n$ - points of the evaluation system (for example, in this task - 10 point evaluation system); $c$ - amount of criteria; $S$ - sum of a criterion points (weight); $X$ - weight coefficient of a criterion.

Example situation. The results of the evaluation are presented in Table 3.

- From the matrix the minimal and maximal values of the criteria should be found: $I_{u}^{\max }=\max \left\{A_{u}\right\}$; $I_{u}^{\min }=\min \left\{A_{u}\right\}$, whereas $I^{\max }-$ maximal value of a criterion; $I^{\mathrm{min}}$ - minimal value of a criterion; $u-$ number of the criteria; $A_{u}$ - set of $u$ criteria of all alternative projects $A_{u}=\left\{I_{u 1}, I_{u 2}, \ldots, I_{u m}\right\} ; m$-amount of alternative projects.
Example situation. There are the following values in the experimental task:

$A_{u}=\max \left\{I_{51}=38, I_{61}=38, I_{72}=44, I_{33}=42\right\}$

and

$A_{u}=\min \left\{I_{11}=19, I_{62}=18, I_{13}=21\right\}$, so $I_{7}{ }^{\max }=44$ and $I_{6}{ }^{\mathrm{min}}=18$. 
Table 3. Comparison of alternative projects

\begin{tabular}{|c|c|c|c|c|c|c|}
\hline \multirow[t]{2}{*}{ Criterion } & \multicolumn{2}{|c|}{ 1. Roundstone Musical Instruments } & \multicolumn{2}{|c|}{ 2. Manitoulin } & \multicolumn{2}{|c|}{ 3. Gift of Course } \\
\hline & Weight & Weight coefficient & Weight & $\begin{array}{c}\text { Weight } \\
\text { coefficient }\end{array}$ & Weight & $\begin{array}{c}\text { Weight } \\
\text { coefficient }\end{array}$ \\
\hline$K_{1}$ & $S_{1}=19$ & $X_{1}=0,27$ & $S_{1}=29$ & $X_{1}=0,41$ & $S_{1}=21$ & $X_{1}=0,30$ \\
\hline$K_{2}$ & $S_{2}=27$ & $X_{2}=0,39$ & $S_{2}=28$ & $X_{2}=0,40$ & $S_{2}=27$ & $X_{2}=0,39$ \\
\hline$K_{3}$ & $S_{3}=31$ & $X_{3}=0,44$ & $S_{3}=29$ & $X_{3}=0,41$ & $S_{3}=42$ & $X_{3}=0,60$ \\
\hline$K_{4}$ & $S_{4}=36$ & $X_{4}=0,51$ & $S_{4}=19$ & $X_{4}=0,27$ & $S_{4}=37$ & $X_{4}=0,53$ \\
\hline$K_{5}$ & $S_{5}=38$ & $X_{5}=0,54$ & $S_{5}=43$ & $X_{5}=0,61$ & $S_{5}=32$ & $X_{5}=0,44$ \\
\hline$K_{6}$ & $S_{6}=38$ & $X_{6}=0,54$ & $S_{6}=18$ & $X_{6}=0,26$ & $S_{6}=29$ & $X_{6}=0,41$ \\
\hline$K_{7}$ & $S_{7}=23$ & $X_{7}=0,33$ & $S_{7}=44$ & $X_{7}=0,63$ & $S_{7}=23$ & $X_{7}=0,33$ \\
\hline
\end{tabular}

- The value of the criterion score should be calculated like this: $B V_{u}=\frac{I_{u}^{\max }-I_{u}^{\min }}{n}$.

Consequently, in this task: $B V_{u}=2,6$.

- Then all the values of each project criterion are calculated in such a way:

$Y_{u i}=\left\{\begin{array}{l}\frac{I_{u i}-I_{u}^{\min }}{B V_{u}} \text { when the increase of value of the criterion is a positive factor, } \\ \frac{I_{u}^{\max }-I_{u i}}{B V_{u} \quad \text { when the decrease of value of the criterion is a positive factor, }}\end{array}\right.$

where, $Y_{u i}$ - is evaluation of a criterion of the project. Only then total project evaluation scores are available (see Table 4).
Example situation. The accumulated results of the evaluation are presented in Table 5. The project which has the largest total score is the recommended one and in this case it is "Gifts of Course".

6. The way of implementation of changes (ICT innovations). The market situation and indicators of the changing environment should be determined. For choosing a method of implementation the threedimensional space of the model analysed above should be used. After the evaluation of business environment changes the criteria of speed of changes, resistance to changes, and strength of changes must be detected and chosen in the knowledge base. Alternative solutions that are offered must be evaluated by an expert group. After that ICT project implementation methodology is recommended.

Table 4. Project evaluation

\begin{tabular}{|c|c|c|c|c|c|}
\hline $\begin{array}{ll}\text { Project } & \text { Criterion } \\
\end{array}$ & $K_{1}$ & $K_{2}$ & $\ldots$ & $K_{c}$ & Total score \\
\hline$I P_{1}$ & $Y_{11}$ & $Y_{21}$ & $\ldots$ & $Y_{c 1}$ & $Z_{1}=\left(X_{1} Y_{11}+X_{2} Y_{21}+\ldots+X_{c} Y_{c 1}\right)$ \\
\hline$I P_{2}$ & $Y_{12}$ & $Y_{22}$ & $\ldots$ & $Y_{c 2}$ & $Z_{2}=\left(X_{1} Y_{12}+X_{2} Y_{22}+\ldots+X_{c} Y_{c 2}\right)$ \\
\hline$\ldots$ & $\ldots$ & $\ldots$ & $\ldots$ & $\ldots$ & $\ldots$ \\
\hline$I P_{m}$ & $Y_{1 m}$ & $Y_{2 m}$ & $\ldots$ & $Y_{c m}$ & $Z_{m}=\left(X_{1} Y_{1 m}+X_{2} Y_{2 m}+\ldots+X_{c} Y_{c m}\right)$ \\
\hline
\end{tabular}

Table 5. Experimental task: project evaluation

\begin{tabular}{cccc}
\hline Criteria & Roundstone Musical Instruments & Manitoulin & Gift of Course \\
\hline $\boldsymbol{K}_{\mathbf{1}}$ & $Y_{11}=4,34$ & $Y_{21}=0,38$ & $Y_{31}=1,15$ \\
\hline $\boldsymbol{K}_{\mathbf{2}}$ & $Y_{12}=6,15$ & $Y_{22}=6,53$ & $Y_{32}=6,54$ \\
\hline $\boldsymbol{K}_{\mathbf{3}}$ & $Y_{13}=4,23$ & $Y_{23}=5$ & $Y_{33}=9,23$ \\
\hline $\boldsymbol{K}_{\mathbf{4}}$ & $Y_{14}=0,38$ & $Y_{24}=6,92$ & $Y_{34}=7,31$ \\
\hline $\boldsymbol{K}_{\mathbf{5}}$ & $Y_{15}=9,62$ & $Y_{25}=7,69$ & $Y_{35}=5,38$ \\
\hline $\boldsymbol{K}_{\mathbf{6}}$ & $Y_{16}=10$ & $Y_{26}=2,31$ & $Y_{36}=5,77$ \\
\hline $\boldsymbol{K}_{\mathbf{7}}$ & $Y_{17}=0$ & $Y_{27}=8,08$ & $Y_{37}=8,08$ \\
\hline & $Z_{1}=\mathbf{1 4 , 4 9 9 4}$ & $Z_{2}=\mathbf{1 6 , 4 4 4 9}$ & $Z_{3}=\mathbf{1 9 , 7 1 2 6}$ \\
\hline
\end{tabular}


7. Implementation. After each evaluation process decisions should be made and the ICT project that was detected should be implemented in the recommended way.

8. Exploitation. After the implementation the exploitation phase lasts until new changes appear.

II. The second way (see Fig. 3) (marked in white boxes) is when a company wants to initiate changes in the market and has an idea. The succession of actions should be the following:

1. Aims and objectives (the aims and objectives of an organization should be determined).

2. Way of implementation of change (the market situation and indicators of the changing environment should be determined, after the finding of an alternative solution, the evaluation should be proceeded, and then ICT project implementation methodology can be recommended).

3. Expert group (the idea must be put in comparison with other cases and should be evaluated by an expert group).

4. Evaluation of alternatives (evaluation process must be preceded)

5. Implementation (decisions should be made and a project implemented).

6. Exploitation (the exploitation phase lasts until new changes).

These two alternative searches for change management solutions enable to shorten the life cycle of an innovative project (finding an idea, preparing the project concept, time spent for preparing documentation), also it helps to minimise the risks of implementation, as well as to detect the most relevant management solution (detect a method for change management).

\section{Conclusions}

1. Nowadays information has become one of the main catalysts for rapid business processes. The tight relation between business management theory and ICT development has been identified. According to the research ICT is a catalyst for the evolution of business management. The shortening periods of natural development of the analysed fields in the $20^{\text {th }}$ century were identified: 20 years at the beginning, 10 years in the middle, 5 years at the end. This is a challenge for business management because of the necessity for quick change management actions.

2. The results of the carried out analysis of change management theories lead to a conclusion that all possible methodologies can be employed to solve the tasks of business change management, caused by ICT development challenges. The progressive methodologies and models of empirical and system theories should be used, attention being paid to the cases of good ICT implementation practice.

3. After the analysis of good ICT practice knowledge base the ICT projects were classified and the rules of search for good practice cases were proposed. Three main dimensions were extracted: market coverage, ICT users and project objectives. Six paradigms which join ICT cases with common parameters were identified. The algorithm which enables to search for change management solutions under ICT development conditions was proposed. It joins management theory and practice, enables to gain a competitive advantage, and shortens the cycle of ICT project implementation.

4. Two alternative search mechanisms how to manage changes (when an organization seeks for an idea of ICT project and when an organization seeks for a better way of implementation of ICT project) were proposed and described.

\section{References}

BEER knowledge system. 2006. Available from Internet: $<$ http://www.beepknowledgesystem.org>.

Casson, M. 1998. Information and organization: a new perspective on the theory of the firm. Oxford: Oxford University Press, 45-46.

Champy, J. 1995. Reengineering management: the mandate for new leadership. New York: Harper Collins Publishers. $240 \mathrm{p}$.

Castells, M. 2003. The Internet galaxy: reflections on the Internet, business, and society. Oxford: Oxford University Press. 292 p.

Elskyte, V. 2006. ICT caused business change management opportunities, in Business development possibilities in the new European area. September, Vilnius: Scientific proceedings, 88-95.

Elskytè, V. 2006. Business change management in ICT development conditions, in Business and management'2006. Vilnius: Technika, 328-334.

E-market services. 2005. Available from Internet:

$<$ http://www.emarketservices.com>.

Ginevičius, R.; Paliulis, N. K.; Chlivickas, E.; Merkevičius, J. 2006. XXI amžiaus iššūkiai: organizaciju ir visuomenès pokyčiai. Kolektyvinė monografija. Vilnius: Technika. 548 p. (in Lithuanian).

Kanter, R. M. 1984. Change-master skills: what it takes to be creative. New York: McGraw-Hill. 432 p.

National best practices. 2005. Available from Internet: $<$ http://www.e-sn.org>.

Strebel, p. 1996. Mastering management: your singlesource guide to becoming a master of management. London: FT Pitman Publishing.

Энииклопедия. Информационные технологии в бизнесе. 2002 [Encyclopedia. ICT in business]. Питер: Бизнескласс. 1115 с. 